\title{
Contemporary Georgian Architectural Theory and Practice: The legacy of Shota Bostanashvili
}

\author{
Lino Bianco ${ }^{1}$
}

Received: $2019-11-11$ | in its final version: 2020-04-24

Abstract

Shota Bostanashvili (1948-2013), a practising architect and a pioneer in developing the poetics of architecture, was a cultural theorist. His philosophy centred around an architectural discourse specifically addressing architecture and linguistic play, and the semiotics of architecture. The objective of this paper is to identify the themes underpinning his philosophy of architecture and his legacy relative to his contemporaries. This paper is based on primary sources including Bostanashvili's buildings, monuments and publications together with unpublished material from the Shota Bostanashvili Archive (Tbilisi). Reference is also made to video footage from the Georgian Public Broadcast, conferences and other sources. This paper concludes by identifying outstanding milestones in Bostanashvili's legacy, both on a pragmatic and a theoretical level. The former relates to the poetics and metapoetics of architecture whilst the latter correlates to architecture as a unique individual spiritual experience and to the poetics of space as part of cultural history rather than phenomenology. He opted for paper architecture as a mode of abstract and poetic expression to approach architecture design education. This paper delves into the margins of normative European architectural historiography. It is a first in documenting in detail the legacy of Shota Bostanashvili, an outstanding Georgian architect, academic, sculptor and poet who is barely known in Western countries, thereby highlighting his impact on the theory of architecture.

Keywords: poetics of architecture; paper architecture; architecture design education; metapoetics

Citation

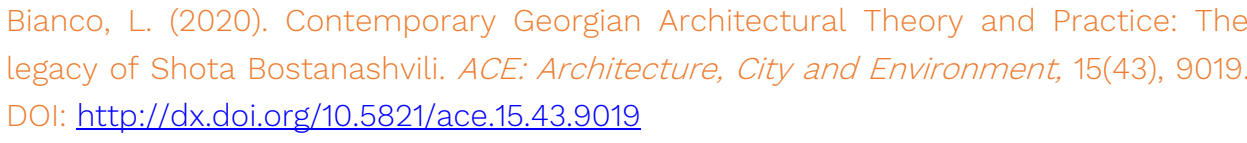

${ }^{1}$ Ph.D., Faculty for the Built Environment, University of Malta, Malta; Faculty of Architecture, University of Architecture, Civil Engineering and Geodesy, Sofia, Bulgaria (ORCID: 0000-0001-8779-2351). Contact e-mail: lino.bianco@um.edu.mt

\section{Introduction}

In his obituary for Shota Bostanashvili, Vakhtang Davitaia describes him as uncompromising and exceptional (Davitaia, 2014). Davitaia, a leading contemporary Georgian architect who has achieved international repute, recalls how architect Giuli Gegelia introduced him to Bostanashvili, then a young student reading architecture at the Georgian Polytechnical Institute. Davitaia also recounts how they worked closely together for almost two decades at the Design Bureau of the Georgian Polytechnic Institute. 
Barely known in the West, Bostanashvili was a preeminent architect, academic, sculptor and poet from Georgia, formerly one of the republics of the Soviet Union. ${ }^{1}$ He was an unassuming, albeit distinguished, academic and practitioner. Lately, various publications have focused on his theory and practice of architecture (Vaklinova, 1997; Bianco, 2017a; Bianco, 2018a; Sekhniashvili and Bostanashvili, 2019) and also critically evaluated his work in relation to the wider architectural milieu of Georgia (Wheeler, 2016).

The aim of this article is to provide an outline of the legacy of this influential architect. Extensive reference is made to his biographical background and to his architectural practice and philosophy of architecture, based on his publications and other primary sources available at the Shota Bostanashvili Archive (SBA), housed at his former residence in Tbilisi, and at the archives of the International Academy of Architecture (IAA) in Sofia. ${ }^{2}$

\section{The man and his architecture}

Bostanashvili's standing has long been recognised and lauded in the former Eastern Bloc. Milestones in his professional and academic career include his architectural works, both realised and conceptual, and the setting up of the studio-workshop 'Poetics of Architecture' at the Georgian Technical University (GTU), Tbilisi.

During Bostanashvili's architectural career, which lasted nearly four decades, he was involved in over a hundred projects. In many of them architecture can be read as an interdisciplinary study incorporating philosophy, semiotics, epistemology, cultural studies and literature (Bostanashvili, D., 2013b). The first overview of Bostanashvili's work was published in 2017 (Bianco, 2017a). It broadly categorised his architectural projects into two phases. The realised projects belonging to the early phase, which commenced in 1970 and spanned over two decades, were undertaken in collaboration mainly with Davitaia. These projects included three memorials - Temple of Memory (1975), Glory to Work (1976) and Cube of Memory (1981), at Mukhrani, Kutaisi and Senaki respectively (Figure 1) - and the Bread Factory in Tbilisi (Figure 2). All of these undertakings were commissioned by the State, the then Soviet Socialist Republic of Georgia.

The proposed residential settlements in the villages of Khakhmati and Biso, Khevsureti region (1973) (Figure 3) and the House of the Actor in Senaki (1987) (Figure 4) were two of his unrealised conceptual designs.

Significant projects belonging to the later phase include the private residence at Vake district (2000) (Figure 5) and the Palace of Poetry (2003) (Figures 6) in Tbilisi, now both demolished, were direct private commissions. His competition entry for a music school in Tbilisi (1990) (Figure 7) represents another unrealised work belonging to this phase.

\footnotetext{
${ }^{1}$ Born in the capital, Tbilisi, in 1948 to a Georgian father and an Iranian mother, both of Jewish descent, Bostanashvili was the eldest of four children. He was educated at 61 School prior to enrolling to read architecture at the Institute of Architecture within the Georgian Technical University (GTU), Tbilisi, where he graduated as an architect in 1972. Until 1990, the GTU was known as the Georgian Polytechnic Institute. Once the university was established, the Faculty of Architecture was renamed the Institute of Architecture. In 2005, the year when Georgia joined the Bologna Process, the faculty became known as the Faculty of Architecture, Urbanism and Design (Mikiashvili, 2013, pp. 8-14).

${ }^{2}$ Given that this article makes use of several publications and other works authored solely by Shota Bostanashvili's son David, references to either of their works are accompanied by the initial of their first name. The SBA is still cataloguing various documents. Thus, although the author did not retrieve particular original documentation from the archive this does not imply that the original documentation does not exist at that location.
}

ACE, 15 (43) CC BY-ND 3.0 ES | UPC Barcelona, Spain | Contemporary Georgian Architectural Theory and Practice: The 
Figure 1. Memorials: (a) Temple of Memory, Mukhrani (top left), (b) Cube of Memory, Senaki (top right) and (c) Glory to Work, Kutaisi (bottom)
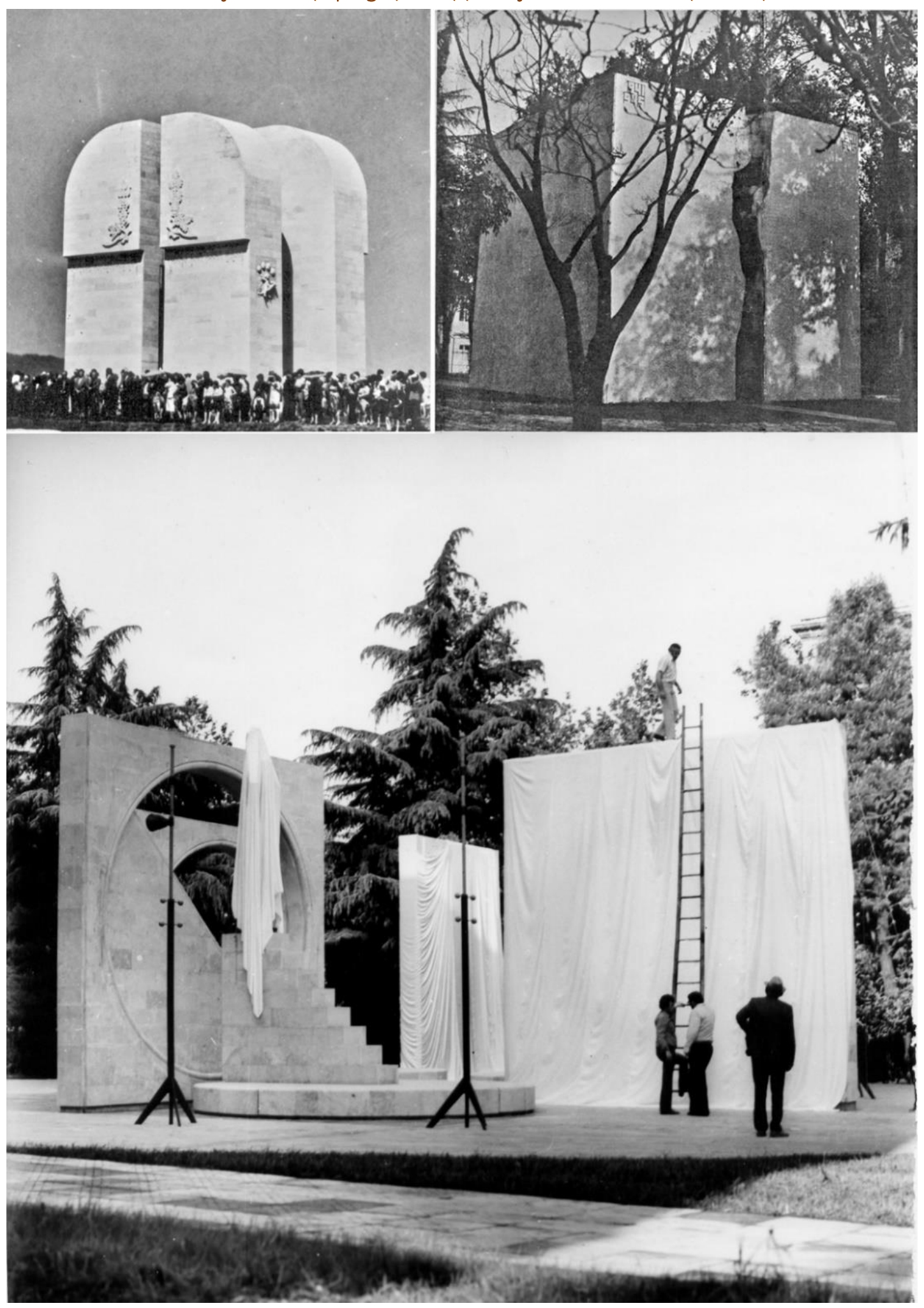

Source: SBA, Tbilisi

ACE, 15 (43) CC BY-ND 3.0 ES | UPC Barcelona, Spain | Contemporary Georgian Architectural Theory and Practice: The 
Figure 2. Bread Factory, Tbilisi: View as in 1980s (top), plan as built (bottom)
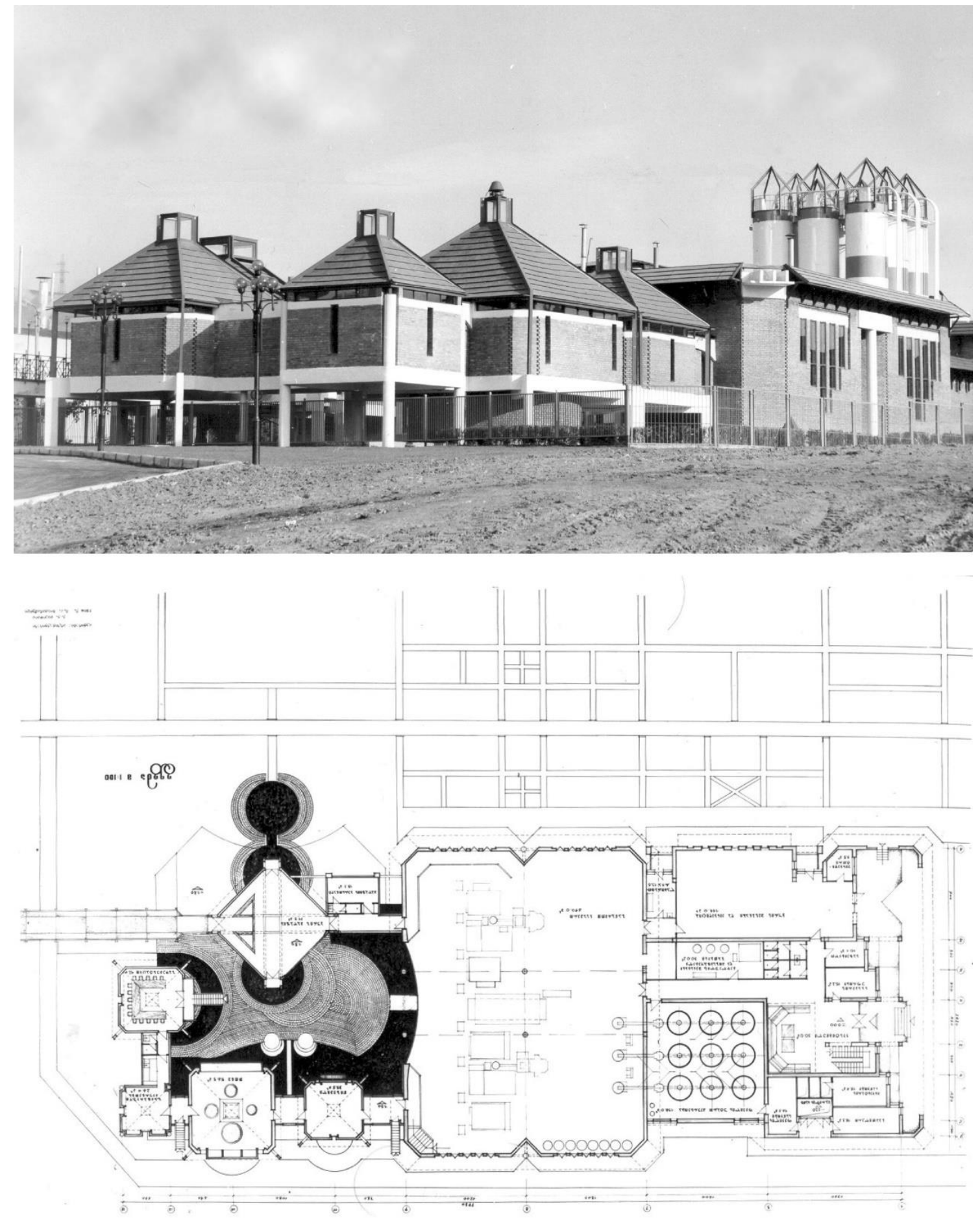

Source: SBA, Tbilisi. 


\section{ACE Architecture, City and Environment}

Figure 3. Proposed residential settlement in Khevsureti region: Conceptual model of settlement at Khakhmati (left) and at Biso (right)

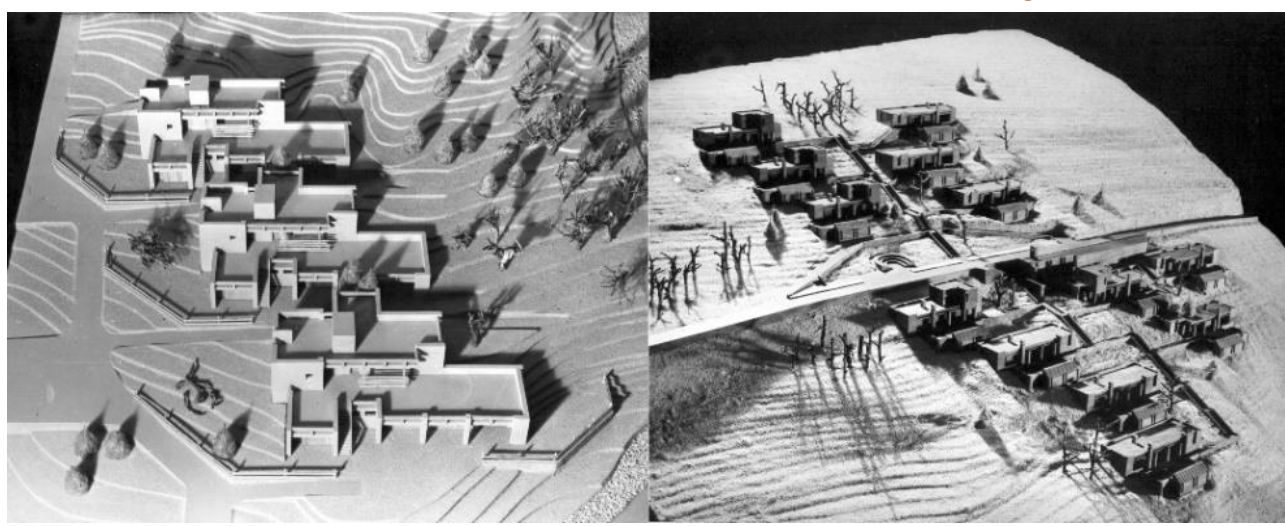

Source: SBA, Tbilisi.

Figure 4. House of the Actor: Model (left) and layout (right)
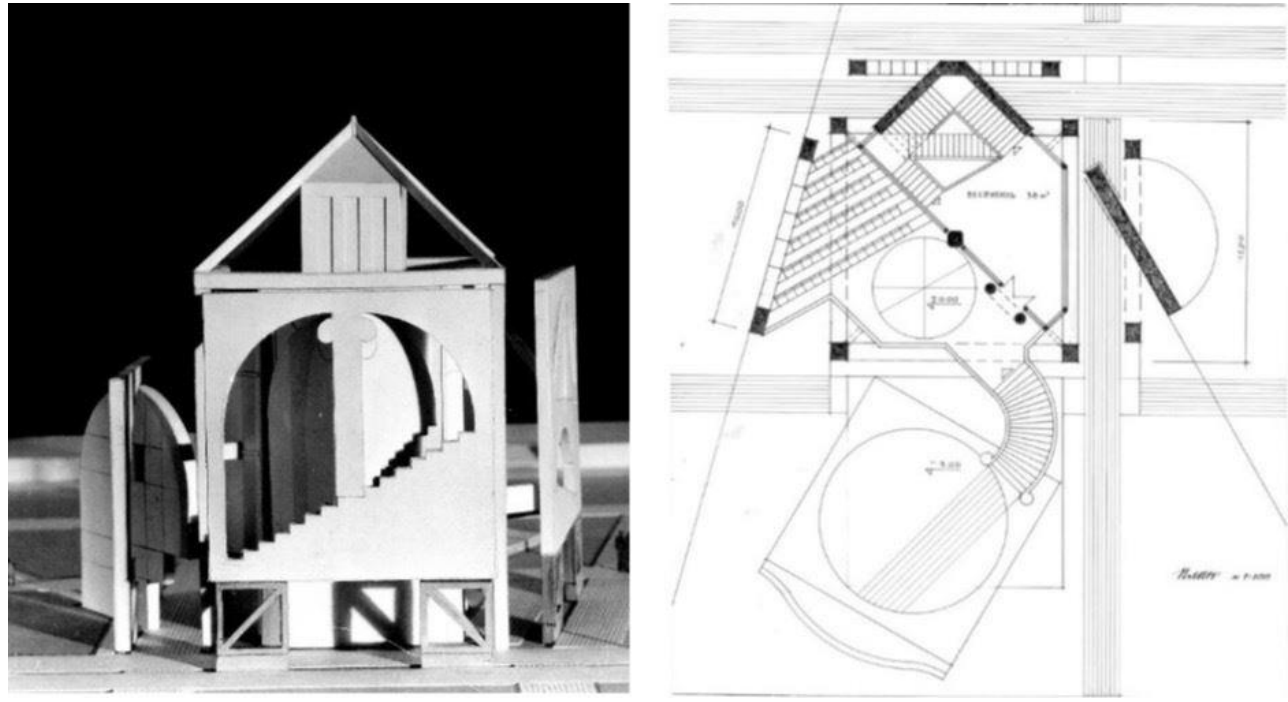

Source: SBA, Tbilisi.

Figure 5. Private residence in Vake district, Tbilisi: Elevation (left) and section (right)
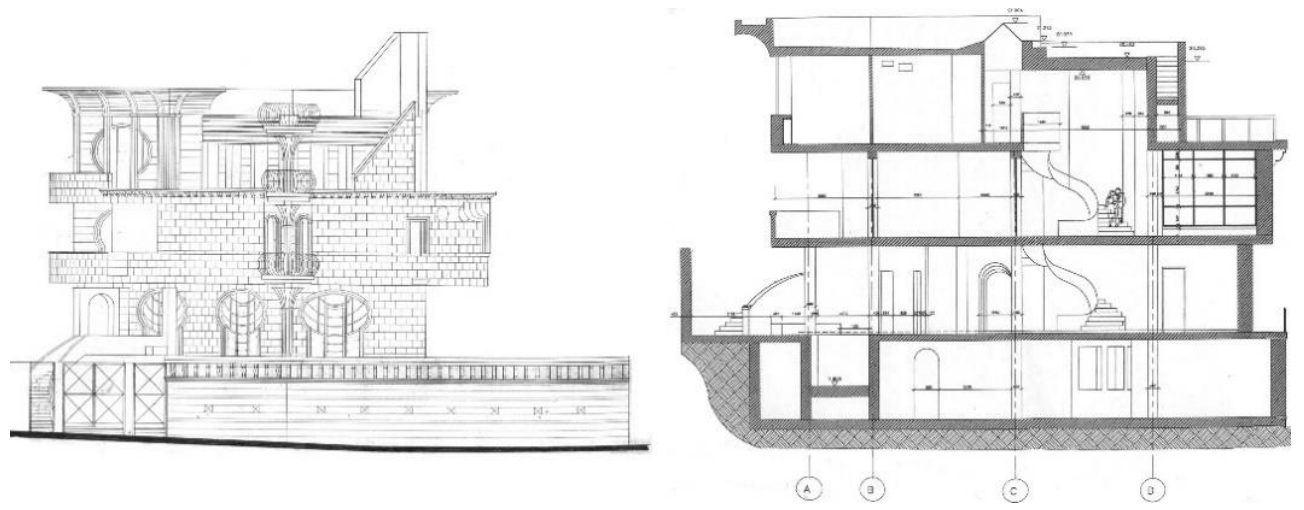

Source: SBA, Tbilisi.

ACE, 15 (43) CC BY-ND 3.0 ES | UPC Barcelona, Spain | Contemporary Georgian Architectural Theory and Practice: The 


\section{ACE Architecture, City and Environment}

Figure 6. The Palace of Poetry, Tbilisi: Sketch (top left), view of towers

(top right), floor plans (middle) and section (bottom)
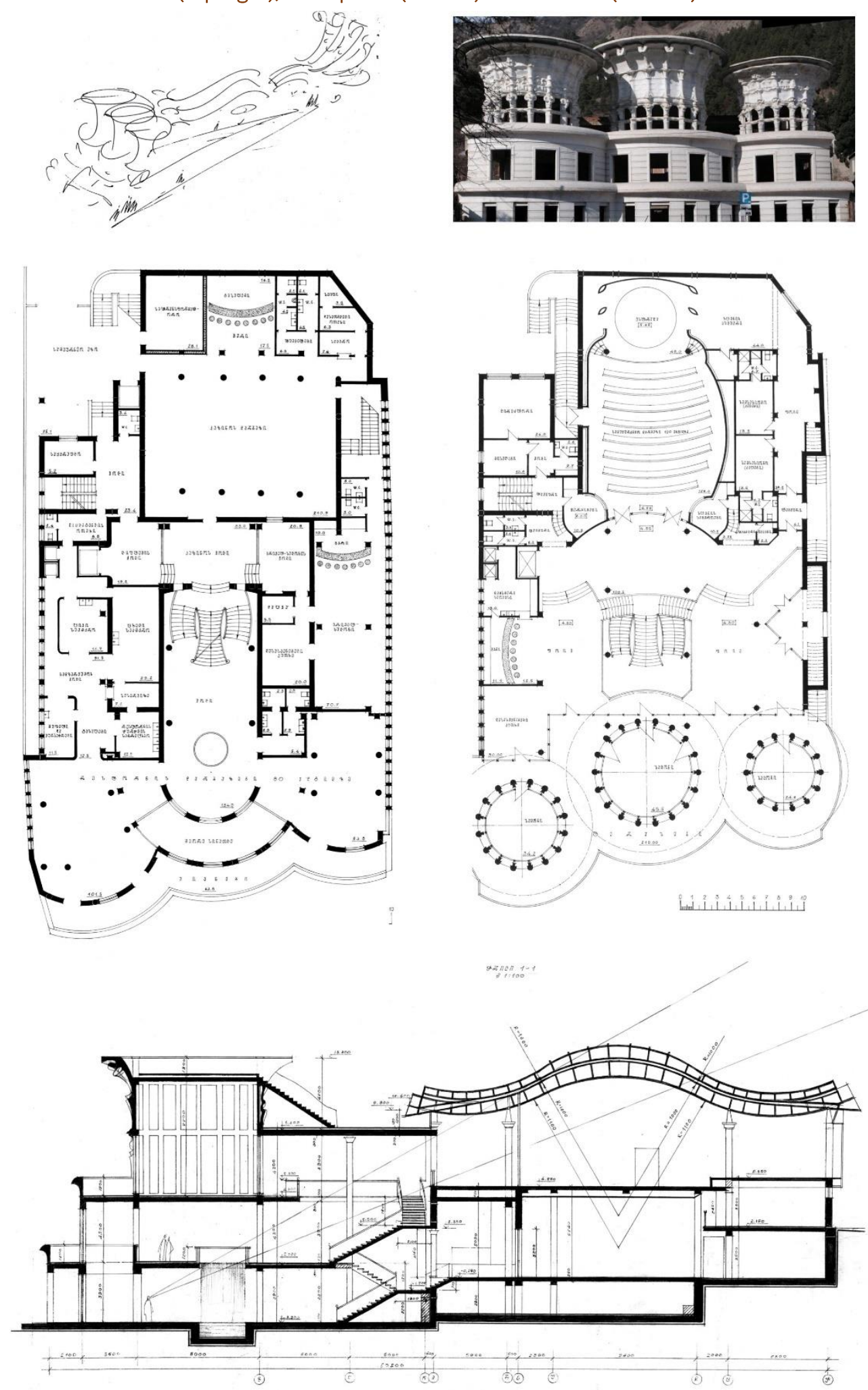

Source: SBA, Tbilisi.

ACE, 15 (43) CC BY-ND 3.0 ES | UPC Barcelona, Spain | Contemporary Georgian Architectural Theory and Practice: The 
Figure 7. Competition entry for a music school, Tbilisi: Site location plan and three-dimensional representation (left) and layout (right)
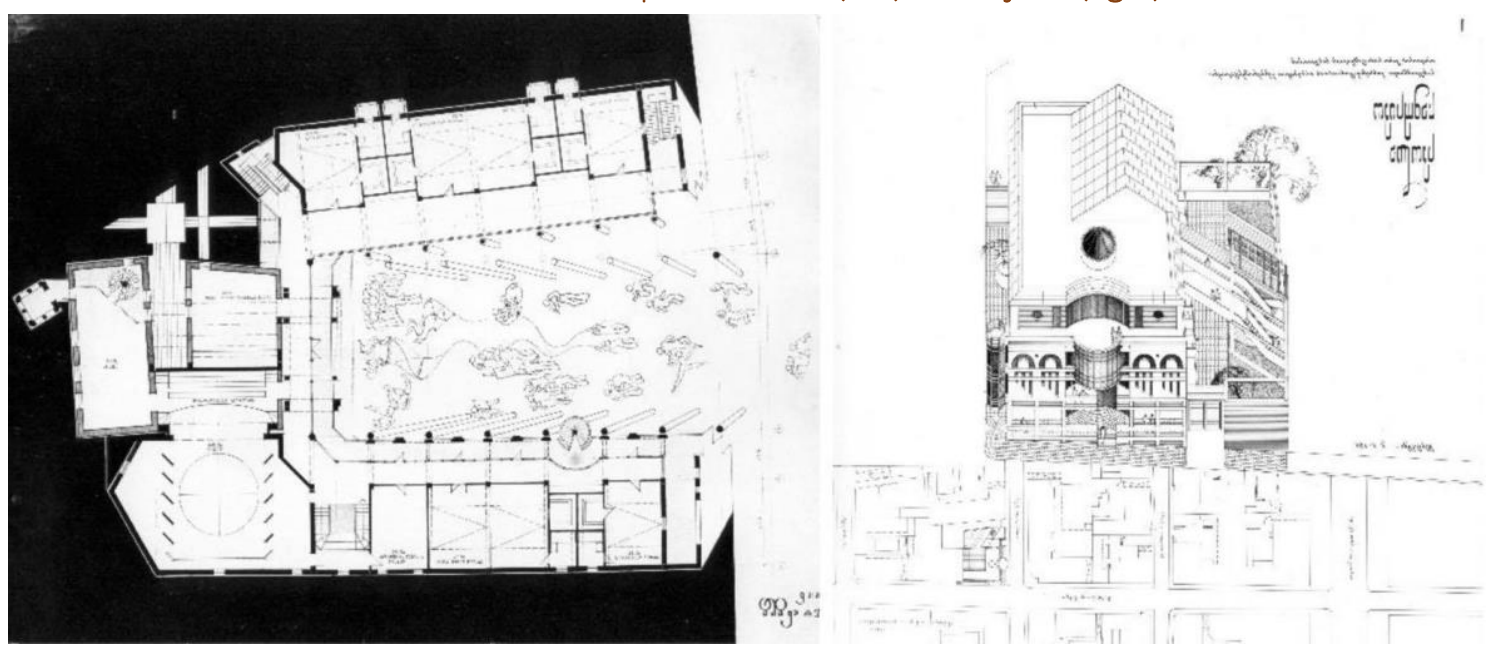

Source: SBA, Tbilisi.

\section{Publications}

Bostanashvili authored several books and articles in scientific journals and newspapers. There are several videos, some available on-line, of him delivering talks, reading poems or being interviewed. Indeed, all these different media can serve to illuminate his contribution to the philosophy of architecture.

\subsection{Books}

Methodologies for architectural composition and design were the theme of Bostanashvili's first book, Methodics of architectural composition and design (Bostanashvili, S., 1993). ${ }^{3}$ The significance of this publication, a short monograph, is that one can trace the early stages of his theory of the poetics of architecture. He demonstrates architecture's capacity to be metaphorical, carry cultural meanings and follow archetypes. Architecture is art, hence it is tasked to carry the burden of expressing the spiritual and material condition of man (society) and not limit itself to the function of a 'shelter'. What tools does architecture possess to achieve this? Physical existence pertains to natural and fabricated objects and is represented through signs, images and names. Another important dimension of this text is that Bostanashvili specifically created a link between the theory of poetics and architectural design, hence the title of the work includes the term 'composition'. In his early academic career, Bostanashvili worked at the Department of Introduction to Architecture which included the academic course 'Composition'. In fact, the Suprematist Compositions of Kazimir Malevich, El Lissitksy and other pioneers of early twentieth century architecture comprised the curriculum of this course, which formed an integral part of architectural education in Soviet institutes. In this text, the term composition persists although it is an empty signifier. The assignments Bostanashvili gave to students during this study unit no longer fitted the category of composition as understood in Soviet era architecture.

\footnotetext{
3 This edition was limited to 200 copies (Jorbenadze, 2019).
} 
In 1998 Bostanashvili published an illustrated book about the architecture of synagogues and Jewish cemeteries in Georgia wherein he outlined their respective cultural significance (Bostanashvili, S., 1998). He approached the topic of this study as a cultural phenomenon with socio-anthropological dimensions. This publication focuses on building typologies briefly addressed in: In the Land of the Golden Fleece: The Jews of Georgia - History and Culture (Arbel et al., 1992). Anthropological aspects of synagogues and Jewish burial sites were addressed in the edited publication of The Israel Museum entitled Mountain Jews: Customs and Daily Life in the Caucasus (Khaimovich, 2002; MikdashShamailov, 2002a; Mikdash-Shamailov, 2002b). Bostanashvili's book was intended to comprise two volumes but the second, which included drawings and an analysis of synagogue architecture in an anthropological context, was incorporated as part of his Ph.D. thesis (Bostanashvili, S., 2008), completed a year prior to the publication of the comprehensive encyclopaedia edited by Avrum Ehrlich (2009).

His poetry book, Four Discourses (Bostanashvili, S., 2012), contains a cycle of four poems each focusing on an element from the classical Greek theory of matter, a theory which dominated philosophy, science and medicine for almost two millennia. The poems on water, fire, air and earth were written in 2004, 2005, 2008 and 2012 respectively. References to the elements do not treat them as themes recurring in ancient Classical Western philosophy and subsequently taken up by philosophy of science. These are not just poems on themes which had inspired a multitude of literary writings, prose and poems worldwide over the centuries. Each poem is a discourse on a given element. For Bostanashvili, the elements do not belong to mythology but to language. In his poetry the Georgian language is expressed in an innovative way, presenting a "semiotic revolution" in Georgian poetry (Lomidze, 2012, p. 6). Words are signs intentionally used as linguistic and non-linguistic terms to signify a specific meaning. At first glance, the poems bring to mind famous examples of visual poetry where the written text has a specific visual and spatial structure. Just like in an architectural drawing, Bostanashvili's poetic text portrays every character in its specific position which serves as a kind of building material. The graphical disjunction of specific phrases and words generates double levels of readings which are not caught automatically when listening to the author reading his poetry aloud. At some moment, the act of listening to poetry turns a reading into a sound performance, generating a surplus of meaning. This misalignment between the written and the spoken word becomes a deconstructive exercise. The process of deconstruction/reconstruction is nothing other than a semiotic revolution wherein the words are given back their ancient significance, or, at times, the words establish new associations born from the conceptual connection of words in the prelinguistic world. Finally, the cycle of poems is a kind of poetic dialogue with The Georgian Dictionary, a work by Sulkhan Saba Orbeliani completed in the early eighteenth century, wherein the poet finds forgotten words of the Georgian language and reintroduces them into contemporary poetic discourse. ${ }^{4}$

The monograph co-written with his son, Butza: Architect Victor Jorbenadze (Bostanashvili and Bostanashvili, 2012) outlines the Bostanashvilis' reading and theory of architecture. ${ }^{5}$ At face value, it reads as a publication on Victor Jorbenadze, a Jewish Georgian architect known as 'Butza' and a personal friend of Eduard Shevardnadze. ${ }^{6}$ This publication has ten chapters, referred to as 'books', an allusion to the treatise De architectura by Marcus Vitruvius Pollio (1914) which consisted of ten chapters similarly termed books. In the preface the Bostanashvilis claim: "With this book we begin a

\footnotetext{
4 The Georgian Dictionary is a notable work by Sulkhan Saba Orbeliani, a Georgian thinker, author and creator of the literary Georgian language. His dictionary, completed in 1713, includes both a lexicon and a compendium of words forgotten in modern Georgian. Bostanashvili retrieved such words related to the elements and gave them new life.

${ }^{5}$ In the edition of the monograph published by Cezanne Printing House, Tbilisi, Jorbenadze's surname is spelled as Djorbenadze. 'Dj' is hard to pronounce and thus it is often written as Jorbenadze (Bostanashvili, D., 2019a). This is the case with the earlier edition of Ltd Universal which has been cited in this article.

${ }^{6}$ Shevardnadze was the Minister of Foreign Affairs of the Soviet Union from 1985 to 1991. Following its dissolution, he became the President of his native Georgia from 1992 until he was forced to retire in 2003 following the bloodless Rose Revolution.
}

ACE, 15 (43) CC BY-ND 3.0 ES | UPC Barcelona, Spain | Contemporary Georgian Architectural Theory and Practice: The 
critical discourse of architecture - reading through differences and narrative where critique takes the task of not just studying ideas but their entropic production. We believe that critical discourse should include impossibility of the discourse (narrative) itself and hindrances - a potential for demythologization" (Bostanashvili and Bostanashvili, 2012, p. 4). ${ }^{7}$ As Vitruvius' work covered most elements of Roman architecture, so does this monograph. It includes an array of elements/themes in critical discourse illustrated through Jorbenadze's work. The significance of the intellectual contribution of this publication to European architecture can be inferred from the fact that the authoritative journal of the Royal Institute of British Architects, the Journal of Architecture, accepted it for review four years after it was published: “... the book is a poetic, quasi-metaphysical dedication to his memory. It is not just a text about an architect; it is a book on architecture. Above all, it is not a text about or on some subject: it is a book that plays. It is a book of architecture as much as it is a book on linguistic play. This fragmentary play of various texts (handwritings, memoirs, articles, photographs and drawings) tells a story of a man who himself was a 'homo ludens' in Johan Huizinga's sense" (Bianco, 2016, p. 459). . "... [the book] is a useful textbook on architectural discourse in general, and during the latter part of the Soviet period in particular. It is a critical treatise on the architectural works and writings of Jorbenadze, ... on how the Bostanasvilis ... read and interpret the architectural language of Butza." (Bianco, 2016, p. 464).

Besides the critical discourse on architecture, Butza is a text about memory, a crucial principle of architecture. It recalls the sixth 'lamp' mentioned in John Ruskin' extended essay of 1849, an essential element for good architecture. As Butza, Jorbenadze's memory is recalled in quasi-metaphysical language so do the memorials Temple of Memory and the Cube of Memory recall the collective psyche.

\subsection{Scientific articles}

Bostanashvili published several scientific articles which not only expounded his views with respect to various themes but also revealed his developing philosophy and theory of architecture. The coauthored monograph included an article by Shota Bostanashvili on the Palace of Ceremonial Rites in Tbilisi, a public building designed by the Jorbenadze (Bostanashvili and Bostanashvili, 2012, pp. 82108). This article appeared in the monthly journal of the Ministry of Culture of the Georgian Soviet Socialist Republic (Bostanashvili, S., 1985). ${ }^{9}$ The building, erected in 1984, was Jorbenadze's last major work. It was commissioned by the Central Committee of the Georgian Communist Party through Shevardnadze, who was at that time the de facto leader of Soviet Georgia.

In the article 'Conflict of boundaries and boundaries of urban conflict', Bostanashvili argued that urban conflict is a global issue (Bostanashvili, S., 2003a). In an architectural context, it implies the tearing up and mixing of urban 'tissue'. Urban conflict in architecture breaks the traditional borders of the law. It is an aggravated form of architectural dialogue and requires the disregarding of the architectural context resulting in the destruction of the known system of signs. Bostanashvili argued that urban conflict can be regarded as a sphere of interest in the semiotics of art and sociocultural systems. It can also be considered as a special case of deconstructive practice.

In 'Image, House, Name', Bostanashvili presented an argument for considering the Court Building in the city of Poti, designed by Gegelia, for a state award (Bostanashvili, S., 2003b). In this publication, Bostanashvili plays with the words 'image', 'house' and 'name', which all sound similar in Georgian.

\footnotetext{
7 Bostanashvili, through his son's doctoral thesis, became convinced that critical discourse was the way ahead for architecture (Bostanashvili, D., 2011).

${ }^{8}$ See Huizinga (1949).

9 The Palace of Ceremonial Rites is also referred to as the Palace of Ceremonies or as the Palace of Rituals. It is one of buildings in the former Eastern Bloc which is representative of Brezhnev-era architecture (Chaubin, 2011).
}

ACE, 15 (43) CC BY-ND 3.0 ES | UPC Barcelona, Spain | Contemporary Georgian Architectural Theory and Practice: The 
He argued that the Court Building was an example of architectural art-work as it departed from the stereotypical typology, and thus the name (court building/court house) did not self-evidently read as the image (the building type), implying that the image defied the name. One could propose to translate Bostanashvili's concepts of 'name' and 'image' into the structuralist terms signifier and signified.

In the obituary for Jacques Derrida, Bostanashvili encounters Derrida with Derridaian writing (Bostanashvili, S., 2006). Here, continuing the theme of linguistic play, he makes a pun on Derrida's name, introducing the concept of veil(ing). 'Ride' is the Georgian word for 'veil'; 'without a veil' is 'uridod' which also means 'without reverence'. The syllable 'u' denotes a negative form; so 'without Derrida' would be 'uderidod'. By allowing language to speak for itself, new concepts arise; some of these, like 'ride' or 'veil', are also applicable to architecture. Veils denote a new architecture: instead of solid statements/signs/architecture, one encounters a veil. Bostanashvili follows a poststructuralist conception of signs when postulating that the veil is "a surface of signifiers pointing to each other": essentially a text (Bianco, 2018a, p. 109). This is not to say that architectural form (signifier) has an absent signified (function). Rather, it elaborates the possibility of new meanings in architecture where the architectural signifier is not fixed to a specific meaning. The Palace of Poetry is a prime example. Here the rich 'texture' of the cast in concrete surfaces point to other signifiers rather than a fixed signified (function). By other signifiers, one implies a chain of visual associations evoked by shapes such as 'flower', 'jellyfish', 'cup'; and, in addition, cultural associations: for example, a tiger's head used as a capital. This signifier not only symbolizes 'the epoch of Rustaveli', as the author stated in one of his interviews, but also acts as an initial signifier in a subsequent chain. For example, one finds numerous buildings with decorative lion's heads in the district where the palace was built. Thus this signified became part of the local architectural text (environment).

Poststructuralist thought is carried on in 'The Sign and the Built' (Bostanashvili and Bostanashvili, 2008) which addresses the semiotics of architecture. Linguistic play through the Georgian language is essential to comprehend this publication. The Georgian words for sign and constructum are 'nishani' and 'nasheni' respectively. The article also introduces the concept of 'destructum', that is, ruins. ${ }^{10}$ In 'Presenting the concept of constructum' (Bostanashvili and Bostanashvili, 2009) linguistic play is taken to a metalevel; it is not only about the creation of language but also an illustration of such praxis. A Manifesto for Constructum was drafted by the Bostanashvilis in 2011 (Bostanashvili and Bostanashvili, 2011) and was included in a number of publications (Bostanashvili, S., 2013a, p. 208; Bostanashvili and Bostanashvili, 2019, p. 104). The concepts of 'nishani', 'nasheni', 'destructum', image, name and house, the six paradigms of architecture, are Bostanashvili's contribution to architecture and some of these concepts come from the Georgian language, thus reflecting a line of thought partly influenced by western philosophy, namely Derrida.

\subsection{Film footage}

Film sources are an important component of the archival sources on Bostanashvili. They serve to further illustrate his gradual exposition regarding his theory of the poetics of architecture, which had unfolded during his lectures and seminars, and wherein one may read his psychology. His approach to teaching was peripatetic. The text came later and, on a number of instances, it read as a momentary focus on a theme relevant to the discipline.

The video footage available at the SBA documents his performative and often provocative teachings about architecture, as well as his artworks. These archival films not only document his lectures,

\footnotetext{
10 This was later developed by Bostanashvili in his lecture, delivered at the Conference of American Studies, entitled Paradigm of Ruins (Bostanashvili, S., 2013b).
}

ACE, 15 (43) CC BY-ND 3.0 ES | UPC Barcelona, Spain | Contemporary Georgian Architectural Theory and Practice: The 
achievements and performances relating to his notion of the poetics of architecture but also activities related to his studio-workshop. The footage falls into two categories:

- events and exhibitions relating to the studio-workshop, and

- the construction and subsequent demolition of the Palace of Poetry.

The earliest footage is of Bostanashvili at a scientific conference at the Ben-Zvi Institute, Jerusalem (Anon, 1990). Most of the films relate to the poetics of architecture; some were aired by the national TV station (Georgian Public Broadcast, 1992; Georgian Public Broadcast, 1995; Georgian Public Broadcast, 1997), others can be found in private collections, whilst others still are available online (Bostanashvili, D., 2001; Bostanashvili, D., 2002b). There is also footage of his architectural projects (Georgian Public Broadcast, 1998), of him and his students from the studio-workshop participating in a conference marking 100 years since the birth of Rene Magritte (Anon, 1999), and a film, dated to the late twentieth century, of his students putting on a performance. This footage was screened in public during the Tbilisi Art Fair 2019 (Anon, 2019).

Moreover, the collection at the SBA includes footage of his Palace of Poetry. In one film, he is seen working and shaping sculptures at a building site (Bostanashvili, D., 2002a) and then reading poems whilst the building is being pulled down (Bostanashvili and Jojua, 2013)..11 Other examples include recordings of him (i) reading his poem "Discourse - Water" and other poems at Café Karavani (Bostanashvili, D., 2008a), (ii) reading his poem "Discourse - Fire" at the Georgian Society for the Visually Impaired (Bostanashvili, D., 2008b), and (iii) reading poems at his home (Bostanashvili, D., 2006; Bostanashvili, D., 2009).

\section{Philosophy of architecture}

\subsection{Poetics of architecture}

The Manifesto for Poetics of Architecture opens with the statement that "one can teach only how to learn" and concludes with another which addresses the beginning not from a beginning but from an end: "The 'Beginning' is depleted; it is already obvious that we have to recreate the 'Beginning' with the ingredients of the 'End'". For Bostanashvili, "Poetics of architecture as a 'new reading', 'critical reading' and as a 'parallel narrative' is an internal movement of modern critical and theoretical practice" (Bostanashvili, S., 2003c). ${ }^{12}$ His philosophy of architecture centred around an architecture discourse that explicitly addressed linguistic play and semiotics in architecture. The philosophy of play served as a creative basis, while semiotics offered a theoretical framework wherein architectural elements are understood as signs that change their meanings depending on the context. These themes had already been discussed with respect to projects he had executed (Bianco, 2017a, pp 5557) in the context of several of his publications (Bostanashvili, S., 2003b; Bostanashvili, S. 2006; Bostanashvili and Bostanashvili, 2008; Bostanashvili and Bostanashvili, 2009). These projects illustrate Bostanashvili's existentialism and philosophy of play (Bianco, 2018a, pp. 105-107), as he himself elaborated in a lecture delivered at the Conference of American Studies held in Tbilisi in 2013 (Bostanashvili, S., 2013b). In this regard, the Cube of Memory, which presents an image of a torn cube with a chaotic interior space, could be understood as referring to the 'human condition' in general, whilst the memorial Glory to Work is organized as a theatre stage. His ideas of play with language in architecture can be particularly noted in the abovementioned early publication in which he put forward the case for the Court Building in Poti (Bostanashvili, S. 2003b).

\footnotetext{
${ }^{11}$ A video clip captured the moment when the towers collapsed (Bostanashvili and Jojua, 2013).

12 Translated and reproduced in Bostanashvili, D. (2019c).
}

ACE, 15 (43) CC BY-ND 3.0 ES | UPC Barcelona, Spain | Contemporary Georgian Architectural Theory and Practice: The 
Based on Bostanashvili's writings (Bostanashvili, S., 2006; Bostanashvili, S., 2010; Bostanashvili and Bostanashvili, 2006; Bostanashvili and Bostanashvili, 2008; Bostanashvili and Bostanashvili, 2009; Bostanashvili and Bostanashvili, 2012), the themes of poetics of architecture and architectural discourse on constructum, the latter being the latest idea he was working on with his son prior to his demise, together with his philosophical shift from poetics to metapoetics of architecture (Bostanashvili, S., 1995; Bostanashvili, D., 2001; Bostanashvili, S., 2003b; Bostanashvili, S., 2010), are discussed elsewhere (Bianco, 2018a, pp. 107-111). Constructum is a notion, based on the concepts of the sign and the built, which addresses issues arising in the semiotics of architecture (Bostanashvili and Bostanashvili, 2008). In the discourse on constructum, or architecture as text, "it is the language itself that works; language about the language that already took hold of the built (history, theory and poetics of architecture)" (Bianco, 2017a, p. 57). Furthermore, instead of talking about poetics, metapoetics addresses the metadiscourse on poetics. The quote on the cover page of his concise portfolio sums up the leap from theory to practice of architecture: "My Metapoetics of Architecture and its practice is my response to the problems of our pragmatic time. This is the main message of the works presented here." (Bostanashvili, S., 2009). A metapoetics of architecture "... fills the vacancies left in place of philosophy and [a]esthetics, the vacancies where the configuration of knowledge is altered. Poetics of Architecture is the adventure of space, the experience of space in terms of culture and namely of architecture. In this regard poetics could, as well, be called culturology of architecture" (Bostanashvili, S., 2013a, p. 207).

The latest publication on Bostanashvili, issued in 2019 (Sekhniashvili and Bostanashvili, 2019), includes a critical reading of the Bread Factory with respect to the other erected public memorials: "The memorials created by Shota are alive, but the Bread Factory is the only building by him that still exists today. It is distinguished by its quality of workmanship. It was conceived as a cultural object from the beginning. This transformation was always happening when he [Shota Bostanashvili] was working. A commission was just one side and its interpretation was another" (Bostanashvili, D., 2019b, p. 89). ${ }^{13}$

In his typically succinct language David Bostanashvili sums up his father's philosophy of architecture and how it resonated with the Soviet system, such that: "... they tell you a factory and you make a house. They tell you a plaque with workers' names and you make a theatre stage in the city, I mean the memorial in Kutaisi. They tell you a mother in crying over her son who never returned from a war, and you make a cube in Senaki that is dedicated to the idea of the birth of geometry from the chaos of plastic. These transformations, strongly seen even in such an object, are important. 'Counterwork' against the Soviet system was easier in case of the memorial. A memorial is a symbol and you answer a symbol with a symbol. In this case, a banal factory is commissioned and you make an object full of narrative - this is significant gesture. At that time, the term narrative was not used as widely as it is used today" (Bostanashvili, D., 2019b, pp. 90-91).

\subsection{Architecture, art, poetry and spiritual development}

Bostanashvili was convinced of the link between architecture, art and poetry. He thought of architecture not merely as a building science but as a spiritual phenomenon manifested in culture. How individuals contribute to architecture and architectural culture? Architecture, just like the other art, helps to foster individual growth. Bostanashvili maintained an uncompromising belief that architecture is a spiritual dimension in an individual. Yet this kind of individual spiritual experience and expression is hard to formulate. Architecture as spiritual development, or as an act of building the self — rather than serving a utilitarian function or as a real-estate commodity — can be seen as a remote and possibly controversial reading in the capital-driven environment of contemporary architecture.

13 This publication recalled a speech David Bostanashvili gave on 3 March 2019 during the Tbilisi Art Fair, 2019.

ACE, 15 (43) CC BY-ND 3.0 ES | UPC Barcelona, Spain | Contemporary Georgian Architectural Theory and Practice: The

legacy of Shota Bostanashvili. DOI: $\underline{\text { http://dx.doi.org/10.5821/ace.15.43.9019 }}$ 
The spiritual reading of science is not a novel idea; one may, for example, refer to the anthroposophical philosophy of Rudolf Steiner (Steiner, 1999). The concept for the Goetheanum at Dornach, developed by Steiner (Blaser, 2002), was to restore global harmony grounded in Johann Wolfgang von Goethe's theory of natural sciences; it was a physical expression of anthroposophical science (Sokolina, 2017). ${ }^{14}$ In this regard some parallels could be established with the Palace of Poetry, but Bostanashvili's work was also a cultural play - an invention of a non-existing Georgian order. Opposition to the monopoly of technological thought is another common strain. The slogan of the Palace of Poetry was 'Return of the Sacred: Dialogue between nature and culture'. Concrete or 'liquid stone', to use the term employed by Sokolina (2017), is indeed an example of the juxtaposition of the natural and the artificial. As for the sacred, it is related to that culturological problem termed 'sacred and profane'. Although some parallels could be made between the two thinkers they remain diametrically opposed. Steiner sought a kind of holism and unity, while Bostanashvili's discourse embraced fragmentation, paradoxes and ambivalence, hence his interest in Derrida's deconstruction. This fragmented nature is also reflected in his work. The Cube of Memory is an image of fragmented form. Bostanashvili never established a formal style. His architecture responds to certain theoretical challenges that originate in culture. While Steiner emphasizes spirituality, for Bostanashvili this word is devoid of esoteric meaning. Spirituality is more associated with creative power and eagerness to play; this spiritual play ultimately contributes to culture at large. Bostanashvili was a cultural theorist rather than a mystic. His references to the Bible and Judaism are guided by his semiotic interests; in Judaism the significance of the written text is central. The deconstructive meanings that arise between the written and the spoken word have been his focus. Other than that, certain Biblical narratives directly relate to broad themes of culture: genesis, deluge, stone steps (ladder); for Bostanashvili these represent paradigms of culture.

\subsection{Phenomenology and poetics of space}

Zahavi, the foremost scholar on Husserl's philosophy and an authority on contemporary phenomenology and its use in the cognitive sciences, notes that

"Phenomenology shares the conviction that the critical stance proper to philosophy requires a move away from a straightforward metaphysical or empirical investigation of objects, to an investigation of the very framework of meaning and intelligibility that makes any such straightforward investigation possible in the first place. It precisely asks how something like objectivity is possible in the first place. Phenomenology has also made important contributions to most areas of philosophy. Contemporary phenomenology is a somewhat heterogeneous field" (Zahavi, 2017).

The post-Second World War reality increased awareness of the significance of human experience, of reflection on socio-cultural contexts, and other considerations. ${ }^{15}$ It was within this context that phenomenology advanced as a mode of reading and making architecture. It was an attempt to comprehend and provide insights into phenomenology in architecture; however, it never developed into a movement as it lacked an aesthetic. Interest in this theme dates back to the early 1950s, and by the late 1970s it had gained a steady momentum, persisting to this day. ${ }^{16}$ In the 1970 s, Dalibor vesely and Joseph Rykwert influenced a generation of architectural scholars towards a

\footnotetext{
${ }^{14}$ For insight to the architectural intentions of Steiner for the Goetheanum building, see Steiner (2003).

15 Team 10 came together at the 9th Congress of the International Congresses of Modern Architecture (CIAM) held in 1953. It challenged CIAM's dogmatic approach to urbanism, leading to a schism and its subsequent dissolution six years later. Structuralism was one of the two architectural movements led by Dutch architects Aldo van Eyck and Jacob Bakema; the other was New Brutalism, led by a British couple, architects Alison and Peter Smithson.

${ }^{16}$ The earliest academic research was at Princeton University; the first Ph.D. thesis was completed by Charles W. Moore (Moore, 1957). In 1960s Europe, Italy was an important crucible. Architects Vittorio Gregotti and Aldo Rossi and their generation were influenced by Ernesto Nathan Rogers, also an architect and editor of the Italian architectural and product design magazine Casabella, at the time known as Casabella Continuità. Rogers collaborated with philosopher Enzo Paci.
}

ACE, 15 (43) CC BY-ND 3.0 ES | UPC Barcelona, Spain | Contemporary Georgian Architectural Theory and Practice: The 
phenomenological approach to architecture.17 In the 1980s, together with his colleague Peter Carl, Vesely continued his teaching and research at the Department of Architecture of the University of Cambridge. Daniel Libeskind was one of his former students and a lifelong friend for 45 years (TaylorFoster, 2015)..$^{18}$ The seminal publication on the subject, Genius Loci: Towards a Phenomenology of Architecture, was authored by the Norwegian architect and architectural theorist Christian NorbergSchulz (1980). ${ }^{19}$

The original starting point of Bostanashvili's shift to the poetics of architecture has a parallel in Vesely. At the start of his influential publication, Architecture in the Age of Divided Representation: The Question of Creativity in the Shadow of Production, Vesely conceded that although stemming from the design studio, his book may at first seem more relevant to the realms of philosophy and the history of ideas than architecture. From the onset he stated the "uneasy feeling that too much is written today about architecture, which should after all communicate visually rather than through words" (Vesely, 2004, p. 3). His trail of thought significantly differs from Bostanashvili's. The latter's writing does not contain direct references to phenomenology as a philosophical school although certain concepts are integrated into his thought. The most significant is Heidegger's oft-cited "language is the house of being". In his triad, Image-Name-House, the term 'name' refers to the sphere of language as seen through phenomenology and semiotics. The second important notion is the concept of place and the symbolic act of 'making place'. Related to this is the notion of boundary. The boundary between opposites marks creation: waters above and below, night and day, and so on. Bostanashvili spoke and wrote extensively on the nature of space and how culture organises space, or, as he termed it, discourse on/of space. His Ph.D. thesis, The Poetics of Space: Architecture of Synagogues and Jewish Graveyards in Georiga (Bostanashvili, S., 2008), is an account of the story of human space beginning from the Garden of Eden. That moment in the movement of thought when material object and immaterial word encounter each other, where nature is translated into language and language into matter, this, he argues, is the birth of architecture (menhirs, dolmens, cromlechs, etc.). Image (concept, nature) unfolds as name and house, whilst sign (word, language) materializes into edifice. In this context one can thus argue that Bostanashvili discusses not only the cultural meaning of space but also its phenomenological dimension.

\subsection{Modernism and Postmodernism}

Bostanashvili's practice and philosophy of architecture mirrors his keenness in poetry, linguistics and literature fostered mainly through the works of Fyodor Dostoevsky and Albert Camus (Bostanashvili, D., 2013a). Retrospectively, can one identify Bostanashvili with any particular style in his unexecuted and realised projects? Did he prefer one style over another? Whilst the memorials, most notably the Temple of Memory, exhibit the existentialist philosophy of Camus, his development proposal for Khevsureti followed the architecture of site synthesis, an architecture grounded in the physical and metaphysical characteristics of a given site (Bianco, 2017b).

The residence in Vake district, seemingly a Classical or even eclectic building with historical references, emerged out of a narrative. The white marble tree of life greeted the visitor when s/he

\footnotetext{
${ }^{17}$ At the time, Vesely and Rykwert directed the School of Comparative Studies at the University of Essex; they developed it into a centre for teaching and research on phenomenology in architecture.

18 Other contemporary leading architects and architectural theorists who, at some time during Vesely's teaching and research career, were tutored by him include Mohsen Mostafavi, David Leatherbarrow, Alberto Pérez-Gómez and Robin Evans (Taylor-Foster, 2015). Libeskind was conferred the title Professor Honoris Causa by the GTU's Faculty of Architecture, Urban Planning and Design in 2012, a year before Bostanashvili's demise.

19 Unlike Norberg-Schulz, who with age became increasingly dissatisfied with the profession and shifted to academia, Bostanashvili never abandoned the practice of architecture. Nowadays, phenomenology is read by architectural students as pivotal to their definition of architecture, the other essential element being the historico-traditional dimension (Bianco, 2018b).
}

ACE, 15 (43) CC BY-ND 3.0 ES | UPC Barcelona, Spain | Contemporary Georgian Architectural Theory and Practice: The

legacy of Shota Bostanashvili. DOI: http://dx.doi.org/10.5821/ace.15.43.9019 
first saw the house from the street, nestled among pine trees. Moving through the house, stone gardens, arched alleys, even natural rock were encountered. These guided the visitor through the narrative of house as a place for being. The architect used the client's mistrust of Modernism as a challenging opportunity. He did not revert to the Classical style but instead revived the craftsmanship of the execution of ideas where no single detail originated from the pre-existing order of industrial paraphernalia; every detail was a result of sketching and imagination, a unique thought process. The tree-shaped balconies were clad in natural stone, cut on site to Bostanashvili's design then fixed using standard metal clips. He questioned the linear narratives of progress, seeing history more as a concurrent web rather than a line of development. There was no return to Classicism because the concept of return itself had been abolished. The Postmodernist presence of the past is deconstructed. The binary pair of past/future is questioned and the state of being between, 'interesse', is introduced. So the Vake building goes beyond Postmodern thought. It recalls the hierarchy of forms (whole, part, detail); it is articulated following Modernist thinking whereby a multiplicity of volumes expressively indicates the spaces they envelop. It conjures a strong poetic narrative with images, making reference to cultural texts (garden, creation, and others) and creates an interior universe where space flows, just as conceptualized by the Modernists.

\section{Bostanashivili's legacy to contemporary architecture}

\subsection{Architecture practice: From existentialism to linguistic play}

Making frequent references to existentialist philosophy during his lectures, Bostanashvili's design projects can be comprehended as a reflection of his existential path in architecture. Referring to Otar Chiladze's allegorical novel issued in 1973, A Man Was Going Down the Road, ${ }^{20}$ Bostanashvili would point that it is always the one who walks on the path, it is always this existential being that creates and adds to the domain of culture. This path does not go through existing or invented styles but, rather, on every turn of this path there is an opportunity to affirm something new. The two points in the Manifesto for Poetics of Architecture can be linked to existentialist thought as well: (i) overcoming the barriers of stereotypical thinking, and (ii) commenting on transgression ('crime') not followed by punishment in the context of art. Borrowing from Dostoyevsky, Bostanashvili plays with the original Russian word for 'crime' which could be read as 'to step over'. Whilst in the pre-historical, Hellenic mythological narrative in the Chiladze' novel one can trace 'magic' realism, Dostoyevsky can be read as a precursor of existentialism. Likewise, in his lectures Bostanashvili would challenge students to confront the idea of stepping over congealed cultural structures of thinking.

\subsection{Architecture theory: Architecture through architecture}

A retrospective exhibition of Bostanashvili's work entitled 'architecture towards architecture' is taken as the starting point of a discourse on architecture. Bostanashvili had set up the studio-workshop 'Poetics of Architecture' with an academic mission: "The main task of the studio is to awaken the abilities that lie dormant inside a child. To feel the joy and excitement of seeing things for the first time. This is the only path and this requires ... spiritual "exercise"' (Bostanashvili, D., 2001). His architectural career is the key to understanding the thinking which underlies his approach to architectural education. His 'human condition', as existentialists would put it, can be read into his early works, which included memorials, a theme fit to explore the symbolic meaning of architecture. From the beginning, one reads the cultural significance of the concept of play in his thought.

\footnotetext{
20 The narrative takes place in Colchis, home of Medea, a region in pre-Hellenistic Greco-Roman geography which corresponds to the contemporary western part of Georgia and other provinces and districts now forming part of presentday Russia and Turkey.
}

ACE, 15 (43) CC BY-ND 3.0 ES | UPC Barcelona, Spain | Contemporary Georgian Architectural Theory and Practice: The

legacy of Shota Bostanashvili. DOI: http://dx.doi.org/10.5821/ace.15.43.9019 
In Bostanashvili's later works, the poststructuralist theory of text is applied to architecture and the basis of all this is the linguistic possibilities of the Georgian language (Bianco, 2018a). In emphasising 'ending' in conditions of a shifted epistemological domain, Bostanashvili introduces a metadiscourse on his own theory thus referring to poetics as metapoetics. The central concepts of his thought Image, House and Name - are presented together with the concept of ruins, which becomes the defining constituent of the new binary pair: constructum (something already built)/destructum (something not yet built or already unbuilt or in a state of ruin). Parallels exist between Bostanashvili's metapoetics and McCaffery's parapoetics (McCaffery, 2008). The links between his series of poems and his architectural writings have already been noted elsewhere (Bianco, 2018a). Poetry became the womb for the architect in his final years as he witnessed the prophecy of ruins fulfilled. His Palace of Poetry was demolished before his eyes. Bostanashvili found his own place in the realm of architecture: all the streams of existential thought, the philosophy of play and the semiotics of culture came together to create a unique architectural philosophy conveyed through the Georgian language.

\subsection{Architecture design education: Paper architecture}

Paper architecture is a mode of expression of abstract and poetic ideas which gained ground in the late 1980s and developed into a new genre of architectural metaphysical conceptualism, an intellectual bridge between nominalism and realism. This led to architectural poetry which provided a new reading of awareness about architecture based on comprehending its social dimension and its links to nature, culture and history. In this context one may argue that both Ilia Lezhava, in Moscow, and Bostanashvili were working contemporarily on the theme of paper architecture. ${ }^{21}$ The latter, who was the junior in age and was based in the capital of Georgia and not of Russia, later used paper architecture as a medium for teaching architecture. It is hard to claim that Bostanashvili was not aware of such thinking. Furthermore, like Lezhava, he did shape architectural thinking but to a smaller public, for two reasons: (i) the Institute of Architecture within GTU is a smaller and less significant school than the Moscow Architectural Institute (MArchi) and (ii) he operated alone, in contrast to the multidisciplinary context at MArchi; he taught alone and had no resources to invite scholars to contribute to his course. Unlike Lezhava, he aimed at sets of rules, creating manifestos for the poetics and metapoetics of architecture. By combining certain theoretical components - philosophy of play, post-structuralism and deconstruction, philosophy of culture and myth, poetics and semiotics - and thus merging architecture with philosophy, literature and poetry, Bostanashvili's work generated a unique personality which is not a representation of an epoch or a style. The course in the poetics of architecture was aimed at how to re-read the history of architecture (Bostanashvili, D., 2019b: p.92). Recalling Bostanashvili's own words, "Poetics of Architecture is philosophy and practice of architecture; it is part of my poetry, it is a method of spatial synthesis, a new conception - movement from words to things and back. It emerged from my architectural practice, went through the 'Paper architecture' and came to conclusion in my academic and pedagogical activity" (Sekhniashvili and Bostanashvili, 2019, p. 73).

\footnotetext{
${ }^{21}$ Lezhava, of Georgian decent from Tbilisi (Davitaia, 2020), was rector of the Moscow Architectural Institute (MArchi), the leading architectural school in Russia which boasts 250 years of history. In an obituary penned by his assistant, he is recalled as the "father of paper architecture" (Kozhushanaya, 2018). Georgia was one of the smallest republics within the former Union of Soviet Socialist Republics (USSR). Nevertheless, various Georgians played key roles in the politics of this former superpower: Stalin, Lenin's successor, was Georgian and so was Shevardnadze, the last Minister of Foreign Affairs of the USSR. Georgians were also prominent in the sphere of architecture: other architects who flourished in Georgia during the Soviet Era include Vladimir Aleksi-Meskhishvili, George Chakhava, Shota Kavlashvili and Jorbenadze. Among those who still dominate the architecture scene in Georgia and Russia are Davitaia and Zurab Tsereteli. Practically all of these architects also produced other artworks, namely paintings and sculptures, these being disciplines which formed an integral part of architecture design education in the former USSR.
}

ACE, 15 (43) CC BY-ND 3.0 ES | UPC Barcelona, Spain | Contemporary Georgian Architectural Theory and Practice: The

legacy of Shota Bostanashvili. DOI: http://dx.doi.org/10.5821/ace.15.43.9019 
The return of myth and poet to architecture was Bostanashivili's original line of thought. Hence, he referred to the archetypes of architecture that represent the cultural basis for the production of symbolic objects (for example, menhirs) and spaces (such as The Temple, which represented the sacred space of Eden). Students were encouraged to think, with poetic metaphors, on architectural themes such as walls, columns or stairs, contemplating them as stand-alone elements divorced from the built context. The work of Rene Magritte was relatable to the studio-workshop; Magritte's paintings are referred to as visual poetry where linguistic strategies of metaphor and metonymy are employed (Dubnick, 1980). In later works by Bostanashvili, references to metaphors, archetypes and myths are avoided as he implements post-structuralist strategies.

\section{Conclusion}

Bostanashvili's theory and practice of architecture exist in a gradual symbiotic harmonic progression. His ideas, and his confidence in interpreting them, matured over time. During his early phase, he worked in a group with other colleagues and towards the end of this period one can discern a marked shift in his philosophy and practice of architecture. One also notes conceptual architectural designs of which he is the sole author. This is more pronounced in the later phase characterized by his opus magnum, the Palace of Poetry, which "ultimately, ... turned out to be [the] chronicle of the death of its architect” (Bostanashvili, D., 2013b).

The key event in his intellectual career was the establishment of the studio-workshop in 1988, a classroom wherein architecture was expounded in the context of the philosophy of culture. When the set-up was belatedly formalised in 1990, it provided a course based on an innovative design technique and rationale for the development of paper architecture. The discourse on architecture (Bianco, 2017a, pp. 55-57) and the poetics and metapoetics of architecture (Bianco, 2018a, pp. 105112) are manifest themes in his research. Another theme is architecture as a spiritual expression of development rather than as a medium to realise utilitarian and/or capital driven real-estate interests. He was keen on cultural theory and not on mysticism. Although there is a parallel with Biblical terms, his interests lay in the link between words and things, and how words translate to objects. His reference to phenomenology was through citations from Heidegger's philosophy of language. His intellectual pursuit was the poetics of space as part of cultural history, rather than of phenomenology.

Bostanashvili was a team player, both in the design office and in the studio-workshop, but not in the strict use of the term. Although he believed that creative power lies only in an individual, he cared for the team and his overwhelming support for each member of the group superseded his own personal success. In the classroom he fostered an approach based on an open sharing of intellectual ideas. Applying the memorial Seafaring Pilgrims (Stanishev, 1989) as a metaphor in both these contexts, whether to architect-colleagues or to students, one can view all individuals like islands floating independently but forming part of the same archipelago.

The commitment to continue running the studio-workshop and its research is still robust at GTU. His son, the main scholar on the poetics of architecture in Georgia, emerged as his intellectual heir, succeeding his father in the chair and now leading the studio-workshop which is "... focused on conceptual reflection on the links between architecture, culture, philosophy and art, and allows students to explore the limits of paper architecture" (Tbilisi Architecture Biennial, 2018).

ACE, 15 (43) CC BY-ND 3.0 ES | UPC Barcelona, Spain | Contemporary Georgian Architectural Theory and Practice: The 


\section{Acknowledgment}

The author would like to express his gratitude to architect Tina Sirbiladze for granting him access to the Shota Bostanashvili Archive and permission to reproduce some of its photos and drawings in this publication, and to Zina Jorbenadze for helping him obtain important details on Georgian publications not available online. The author would like to thank David Caruana for his valuable comments on an earlier version of this paper.

Conflict of interests: The author declares that there is no conflict of interests.

\section{Bibliography}

Anon (1990). Shota Bostanashvili at a scientific conference. Jerusalem, Israel: Ben-Zvi Institute. Video footage. Tbilisi, Georgia: Shota Bostanashvili Archive. (In Georgian).

Anon (1999). Today is Magritte's climate. Video footage. Tbilisi, Georgia: Shota Bostanashvili Archive. (In Georgian).

Anon (2019). Shota Bostanashvili's and his students' performance in 1998 at Tbilisi State Academy of Arts during the workshop entitled 'Imagining Tbilisi'. Video footage. Tbilisi, Georgia: Shota Bostanashvili Archive. (In Georgian).

Arbel, R.; Magal, L., \& Goldman, B. (Eds.). (1992). In the Land of the Golden Fleece: The Jews of Georgia - History and Culture. Tel Aviv, Israel: Beth Hatfutsot.

Avrum Ehrlich, M. (Ed.). (2009). Encyclopaedia of the Jewish Diaspora: Origins, Experiences and Culture. Santa Barbara, USA: ABC-CLIO.

Bianco, L. (2016). Butza: Architect Victor Jorbenadze. The Journal of Architecture, 21(3), 459-464. DOI: https://doi.org/10.1080/13602365.2016.1183384

Bianco, L. (2017a). Shota Bostanashvili, architectural discourse and the foundation of poetics of architecture in Georgia. Papers of BAS: Humanities and Social Sciences, 4(1), 49-59. Retrieved from https://www.um.edu.mt/library/oar//handle/123456789/27598

Bianco, L. (2017b). Beyond Geodesign: The architecture of sitesynthesis. Journal of Applied Engineering Sciences, 7(2), 17-24. DOI: https://doi.org/10.1515/jaes-2017-0008

Bianco, L. (2018a). From poetics to metapoetics: Architecture towards architecture. Balkan Journal of Philosophy, 10(2), 103-114. DOI: https://doi.org/10.5840/bjp201810212

Bianco, L. (2018b). Defining architecture: a qualitative research. Annual of the University of Architecture, Civil engineering and Geodesy Sofia, 51(1), 59-66. Retrieved from https://www.um.edu.mt/library/oar//handle/123456789/34084

Blaser, W. (2002). Nature in Buildings: Rudolf Steiner in Dornach 1913-1925. Stuttgart, Germany: Birkhauser.

ACE, 15 (43) CC BY-ND 3.0 ES | UPC Barcelona, Spain | Contemporary Georgian Architectural Theory and Practice: The 
Bostanashvili, D. (2001). ${ }^{22}$ Architecture towards architecture. Video footage. (In Georgian). Retrieved from https://youtu.be/vTUiH56NsQQ

Bostanashvili, D. (2002a). Shota Bostanashvili working and shaping the Palace of Poetry on site. Video footage. Tbilisi, Georgia: Shota Bostanashvili Archive. (In Georgian).

Bostanashvili, D. (2002b). On Poetics of Architecture at Rustaveli Institute of Literature. Video footage. Tbilisi, Georgia: Shota Bostanashvili Archive. (In Georgian).

Bostanashvili, D. (2006). Shota Bostanashvili reading poems: Clip 1. Video footage. Tbilisi, Georgia: Shota Bostanashvili Archive. (In Georgian).

Bostanashvili, D. (2008a). Shota Bostanashvili reading his poems at Café Karavani. Video footage. Tbilisi, Georgia: Shota Bostanashvili Archive. (In Georgian).

Bostanashvili, D. (2008b). Shota Bostanashvili reading a poem at the Georgian Society for visually impaired. Video footage. (In Georgian). Retrieved from https://youtu.be/xloiZqnWIUY

Bostanashvili, D. (2009). Shota Bostanashvili reading poems: Clip 2. Video footage. Tbilisi, Georgia: Shota Bostanashvili Archive. (In Georgian).

Bostanashvili, D. (2011). Sign and Constructum (Doctoral thesis). Georgian Technical University, Tbilisi. (In Georgian).

Bostanashvili, D. (2013a). Architect’s Own time. Style, 46, 60-63. (In Georgian).

Bostanashvili, D. (2013b). Flowers of Stone. Retrieved from https://flowersofstone.wordpress.com/english/

Bostanashvili, D. (August 25 $\left.5^{\text {th }}, 2019 a\right)$. Messenger.

Bostanashvili, D. (2019b). The Bread Factory. In N. Sekhniashvili \& D. Bostanashvili (Eds.), Shota Bostanashvili: Poetics of Architecture (pp. 89-93). Tbilisi, Georgia: Posta.

Bostanashvili, D. (2019c). Poetics of Architecture: Six names. In N. Sekhniashvili \& D. Bostanashvili (Eds.), Shota Bostanashvili: Poetics of Architecture (pp. 94-103). Tbilisi, Georgia: Posta.

Bostanashvili, D. \& Jojua, S. (2013). The demolition of the Palace of Poetry. Video footage. (In Georgian). Retrieved from https://youtu.be/q3BDtEt7wDU

Bostanashvili, S. (1985). Palace of Ceremonial Rites in Tbilisi. Sabchota Khelovneba, 8, 16-27. (In Georgian).

Bostanashvili, S. (1993). Methodics of architectural composition and design. Tbilisi, Georgia: Georgian Technical University. (In Georgian).

Bostanashvili, S. (1995). Unpublished leaflet of the exhibition marking the five years since the setting up of the studio-workshop Poetics of Architecture. Tbilisi, Georgia: Shota Bostanashvili Archive. (in Georgian).

22 In Bianco (2018a) this reference is included as Bostanashvili, S. (2001). Speech at the opening of the exhibition Architecture towards Architecture held on November 16, 2001.

ACE, 15 (43) CC BY-ND 3.0 ES | UPC Barcelona, Spain | Contemporary Georgian Architectural Theory and Practice: The 
Bostanashvili, S. (1998). The Architecture of Synagogues and Jewish Graveyards in Georgia. Tbilisi, Georgia: Nisan Babalikashvili Material culture foundation of Georgian Jews.

Bostanashvili, S. (2003a). Conflict of boundaries and boundaries of urban conflict. Kavkasiis Matsne, Special Issue, 2, 99-103. (In Georgian).

Bostanashvili, S. (2003b). Image, House, Name. Literaturuli Sakartvelo, 50, 12. (In Georgian).

Bostanashvili, S. (2003c). Poetics of Architecture. Tbilisi, Georgia: Shota Bostanashvili Archive. (In Georgian).

Bostanashvili, S. (2006). Sans reverence and sans veils. Sdjani, 7, 128-136. (In Georgian).

Bostanashvili, S. (2008). The Poetics of Space: Architecture of Synagogues and Jewish cemeteries in Georgia (Doctoral thesis). Georgian Technical University, Tbilisi. (In Georgian).

Bostanashvili, S. (2009). Design Portfolio: Shota Bostanashvili. Tbilisi, Georgia: Shota Bostanashvili Archive.

Bostanashvili, S. (2010). Poetics of Architecture. Retrieved from https://gtu.ge/Arch/Poetics/index.html

Bostanashvili, S. (2012). Four Discourses. Tbilisi, Georgia: Ltd Universal. (In Georgian).

Bostanashvili, S. (2013a). Poetics of Architecture. In G. Mikiashvili (Ed.), Faculty of Architecture, Urban Planning and Design 1922-2012 (pp. 195-208). Tbilisi, Georgia: Georgian Technical University.

Bostanashvili, S. (2013b). Paradigm of Ruins: Lecture delivered at the Conference of American Studies. Tbilisi, Georgia: Shota Bostanashvili Archive. (in Georgian).

Bostanashvili, S. \& Bostanashvili, D. (2006). Unpublished excerpt from the explanatory note to the competition entry exhibited at Karvasla Centre. Tbilisi, Georgia: Shota Bostanashvili Archive. (In Georgian).

Bostanashvili, S. \& Bostanashvili, D. (2008). The sign and the built. Semiotika, 4, 76-86. (In Georgian).

Bostanashvili, S. \& Bostanashvili, D. (2009). Presenting the concept of constructum. Semiotika, 5, 117123. (In Georgian).

Bostanashvili, S. \& Bostanashvili, D. (2011). Manifesto for Constructum. Tbilisi, Georgia: Shota Bostanashvili Archive. (In Georgian).

Bostanashvili, S. \& Bostanashvili, D. (2012). Butza: Architect Victor Jorbenadze. Tbilisi, Georgia: Ltd Universal.

Bostanashvili, S. \& Bostanashvili, D. (2019). Manifesto for Constructum. In N. Sekhniashvili \& D. Bostanashvili (Eds.), Shota Bostanashvili: Poetics of Architecture (p. 104). Tbilisi, Georgia: Posta.

Chaubin, F. (2011). CCCP: Cosmic Communist Constructions Photographed. Cologne, Germany: Taschen Gmbh. 
Chiladze, O. (1973). A Man Was Going Down the Road. Tbilisi, Georgia: Merani Publishing. Trans. D. Rayfield. London, United Kingdom: Garnett Press, 2012.

Davitaia, V. (June $3^{\text {rd }}$, 2014). Exceptional - Remembering Shota Bostanashvili. Sakartvelos Respublika, 6. (In Georgian).

Davitaia, V. (March 30th 2020$)$. Query: Ilia Lezhava. Email. Translated by D. Bostanashvili.

Dubnick, R. (1980). Visible Poetry: Metaphor and Metonymy in the Paintings of René Magritte. Contemporary Literature, 21(3), 407-419.

Georgian Public Broadcast (First Channel) (1992). Shota Bostanashvili on Poetics of architecture. Video footage upload on 2014, November 1. (In Georgian). Retrieved from https://youtu.be/FGV6AVjOJ5s

Georgian Public Broadcast (First Channel) (1995). Studio Poetics of Architecture 5th year anniversary. Video footage upload on 2013, February 11. (In Georgian). Retrieved from https://www.facebook.com/watch/?v=504858539556247

Georgian Public Broadcast (First Channel) (1997). Studio Poetics of Architecture at Interarch97. Video footage upload on 2013, March, 18. (In Georgian). Retrieved from https://youtu.be/Vq3olEGIRg|

Georgian Public Broadcast (First Channel) (1998). Shota Bostanashvili's exhibition at Union of Architects, celebrating 50-year anniversary. Video footage. (In Georgian). Tbilisi, Georgia: Shota Bostanashvili Archive.

Huizinga, J. (1949). Homo Ludens: A Study of the Play-Element in Culture. London, United Kingdom: Routledge and Kegan Paul.

Jorbenadze, Z. (September $\left.5^{\text {th }}, 2019\right)$. Messenger.

Khaimovich, B. (2002). The characteristics features of Caucasian Jewish construction. In L. MikdashShamailov (Ed.), Mountain Jews: Customs and Daily Life in the Caucasus (pp. 65-78). Jerusalem, Israel: The Israel Museum.

Kozhushanaya, E. (2018). About Lezhava. (In Russian). Retrieved from https://archi.ru/russia/80974/olezhave

Lomidze, G. (2012). Mystery play of revelation in the bosom of grammar. In S. Bostanashvili, Four Discourses (pp. 5-7). Tbilisi, Georgia: Ltd Universal. (In Georgian).

McCaffery, S. (2008). Parapoetics and the Architectural Leap. In J. J. Bono, T. Dean \& E. P. Ziarek (Eds.), A Time for the Humanities: Futurity and the Limits of Autonomy (pp. 161-179). New York, USA: Fordham University Press.

Mikiashvili, G. (Ed.) (2013). Faculty of Architecture, Urban Planning and Design 1922-2012. Tbilisi, Georgia: Georgian Technical University.

Mikdash-Shamailov, L. (2002a). The cycle of the year. In L. Mikdash-Shamailov (Ed.), Mountain Jews: Customs and Daily Life in the Caucasus (pp. 79-92). Jerusalem, Israel: The Israel Museum.

ACE, 15 (43) CC BY-ND 3.0 ES | UPC Barcelona, Spain | Contemporary Georgian Architectural Theory and Practice: The 
Mikdash-Shamailov, L. (2002b). The life cycle. In: L Mikdash-Shamailov (Ed.), Mountain Jews: Customs and Daily Life in the Caucasus (pp. 93-110). Jerusalem, Israel: The Israel Museum.

Moore, C. W. (1957). Water and Architecture (Doctoral thesis). Princeton University, New Jersey.

Norberg-Schulz, C. (1980). Genius Loci, Towards a Phenomenology of Architecture. New York, USA: Rizzoli.

Ruskin, J. (1849). The Seven Lamps of Architecture. London, United Kingdom: Smith, Elder, and Co.

Sekhniashvili, N. \& Bostanashvili, D. (Eds.) (2019). Shota Bostanashvili: Poetics of Architecture. Tbilisi, Georgia: Posta.

Sokolina, A. P. (2017). Biology in Architecture: The Goetheanum Case Study. In C. N. Terranova \& M. Tromble (Eds.), The Routledge Companion to Biology in Art and Architecture (pp. 52-70). New York, USA: Routledge.

Stanishev, G. (1989). A Space for the 21st Century Civilisation. World Architecture, 3, 68-71.

Steiner, R. (1999). Architecture as a Synthesis of the Arts. New York, USA: Rudolf Steiner Press.

Steiner, R. (2003). Architecture. Forest Row, East Sussex, United Kingdom: Sophia Books.

Taylor-Foster, J. (April 3 ${ }^{\text {rd }}$, 2015). The Life of Dalibor Vesely: Teacher, Philosopher, Acclaimed Academic. ArchDaily. Retrieved from https://www.archdaily.com/615659/dalibor-vesely-obituary

Tbilisi Architecture Biennial (2018). Monocle on Design: Tbilisi's hopeful horizons. Retrieved from http://biennial.ge/david-bostanashvili/

Vaklinova, E. (1997). Spatial Synthesis in works of Shota Bostanashvili. AMC Aspekty, 3, 32-34. (In Bulgarian).

Vesely, D. (2004). Architecture in the Age of Divided Representation: The Question of Creativity in the Shadow of Production. Cambridge, USA: MIT Press.

Vitruvius, M. P. (1914), The Ten Books on Architecture. Trans. M. H. Morgan. Cambridge, USA: Harvard University Press.

Wheeler, A. (2016). Socialist in Form, National in Content: Preserving late Soviet culture at Thilisi Palace of Rituals (Master thesis). Columbia University, New York. Retrieved from https://academiccommons.columbia.edu/doi/10.7916/D88W3DFD

Zahavi, D. (2017). Husserl's Legacy: Phenomenology, metaphysics, and transcendental philosophy. Oxford, United Kingdom: Oxford University Press. 